\title{
WATER BUDGET POSITION AND ITS IMPLICATIONS ON BASIN MANAGEMENT IN URBANIZED CATCHMENT IN A TROPICAL CITY OF ILORIN, NIGERIA \\ Iroye, K.A. \\ http://dx.doi.org/10.4314/ejesm.v6i4.3
}

Received 14th February 2013; accepted 25th June 2013

\begin{abstract}
The study investigates water budget position in Ilorin, Kwara State Nigeria using temperature and rainfall data collected from Nigerian Meteorological Agency (NIMET) at Ilorin International Airport for a period of ten years. From the temperature record, the evapotranspiration values were computed for the city using modified Thorntwaite (1948) formula. Water budget graph was subsequently posted using the rainfall and computed evapotranspiration data. Result obtained indicates that the month of September received the highest mean monthly rainfall while lower rainfall values were recorded in the months of January, February, November, and December. The mean monthly temperature was fairly constants throughout the year while evapo-transpiration values were generally high during the dry season. Water budget graph plotted indicates that soils in the study area were at deficits between of November and late April while significant water surplus condition was observed between May and October. The water surplus position in August was however observed to be relatively low. Reason for this may not be unconnected with the short dry spell condition which is usually experienced in the study area around this period. The study subsequently examined the implications of its findings on basin management within and around the city.
\end{abstract}

\section{Introduction}

The effectiveness of rainfall in producing runoff in any geographical area is dependent on the changing balance between runoff and evaporation losses. This relationship which is often illustrated by soil moisture budget exhibits both spatial and temporal variations (Ayoade, 1988). While the factors of soil, slope and topography can be held accountable for the variations in soil moisture over a climatically homogenous area, the varying amounts of precipitation and evapotranspiration values accounts for the temporal variations (Ayoade, 1976). However, influence of climatic conditions, especially those of precipitation and evaportranspiration can also be responsible for some spatial variations in soil moisture.

The importance of soil moisture in both agricultural production and hydrological activities of any area cannot be overemphasized. While plants depend on it for growth and photosynthesis (Slatyer, 1967; Winter, 1974; Jackson, 1977), it is of great importance in determining the proportion of precipitation which will appear as surface runoff (Atoyebi, 1995; Jimoh and Iroye 2009). So also, since soil nutrients can only be absorbed by plants in solution, lack of soil moisture will deprive any plants, of both moisture and nutrients required for growth and development.
The relevance of soil moisture factor in influencing flood is well demonstrated by works of Olaniran (1983), Oyegun (1983) and Iroye (2008) among others. According to Oyegun (1983), when rainfall exceed potential evaporation, soil moisture reserves are recharged. When optimum soil-moisture capacity is attained, further rainfall is classified as surplus and may cause flood. Olaniyan (1983) reported the yearly september surplus in Ilorin as being the cause of frequent flood events in the city. Examination of soil moisture condition as being currently carried out in this investigation will thus aid in solving the myriad of challenges being confronted in area of basin management, this is by indicating the period when there is likely to be water deficiency or drought, periods when flooding is likely to occur, the best time for irrigation, longer time changes in storage of a basin and the need for a water transfer system.

However, despite the importance of soil moisture factor in watershed management, it is not routinely measured (Ayoade, 1988). This is due to the fact that the amount of moisture measured at a given location cannot be said to be representative of the area around such a location. Not only that, the procedure for its measurement are rather time consuming (e.g. gravimetric method) or expensive (e.g neutron probe). Thus, only water budgeting approach provides a 
Water Budget Position and its Implications on Basin Management in Urbanized...............Iroye, K.A.

relatively rapid and cheaper method for estimating soil moisture amount, hence its examination in this study towards solving the increasing challenges of basin management in the city. Specifically however, the study seeks to:

i. examine the climatic variables of rainfall and temperature for the study period,

ii. compute evapo-transpiration values for the study period using temperature data,

iii. plot water budget graph for the study period using (i) and (ii) iv. relate the water budget graph plotted to environmental processes operating in the study area, and

v. suggest based on the findings, the management techniques that can be adopted in ameliorating environmental problems in the study area.

\section{The Study Area}

Ilorin, the capital city of Kwara State, Nigeria is the study area in this investigation (Figure 1).

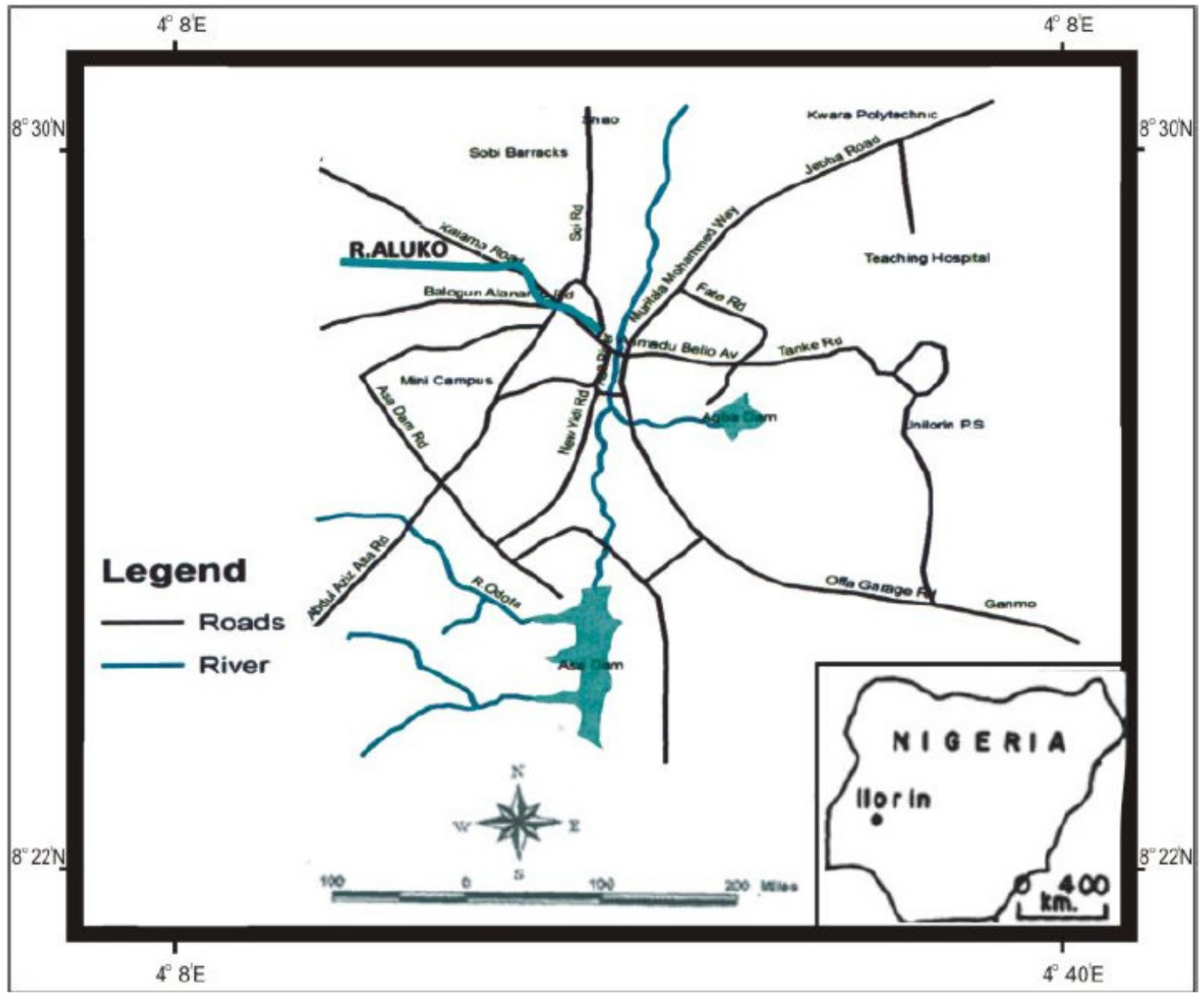

Figure 1 Map of Ilorin showing the Study Area

The city is located between latitude $8^{0} 24^{\prime}$ and $8^{0} 36^{\prime}$ North of the equator and between longitudes $410^{\prime}$ and $4^{0} 36^{\prime}$ East of the Greenwish meridian (Oyegun, 1983). Ilorin is a transition zone between the deciduous woodland of the south and dry savanna of north of Nigeria (Jimoh, 2003). The city has an approximate area of $150 \mathrm{sq} . \mathrm{km}$ and a population of about 847,582 (NPC, 2007).

Ilorin has a humid tropical climate which is characterized by wet and dry seasons. The temperature in the city is uniformly high throughout the year and open air insolation according to Oyegun (1983) can be very uncomfortable during the dry season. The mean monthly temperatures are usually very high varying between $25.1^{\circ} \mathrm{C}$ in August and $30.3^{\circ} \mathrm{C}$ in March. The diurnal range of temperature is also high in the area. Rainfall in Ilorin is produced by tropical continental airmass and it exhibits great variability both temporarily and spatially. The mean annual rainfall in the area is about $1200 \mathrm{~mm}$ (Olaniran, 2002), Relative humidity in the city during the wet season is between 75 to 
$80 \%$ while in the dry season it is about $65 \%$ (Tinuoye, 1990).

The geology of Ilorin is made up of Precambrian rock basement complex rocks which are neither porous nor permeable except in places where they are deeply weathered or have zone of weakness (Jimoh, 1997). Large area of the town is also underlined by sedimentary rocks which contain both primary and secondary lateritic deposits. Soil type in the city is made up of both sandy and clayey deposits. While the sandy deposit is characterized by low water holding capacity which encourage infiltration, the clayey deposit beneath results in water lodging during rainy season thus encouraging run off generation in the city. Ilorin is mainly drained by River Asa and its tributaries such as Aluko, Alalubosa, Okun, Osere Agba and Atikeke (Jimoh and Iroye, 2009).

Vegetation in the city comprises of tall grasses which are interspersed with scattered trees. Examples of trees in the area include lophira lanceolata, terminaalia glauscens and afzelia Africana while bekeropsis uniseta, monocymbium cresilforme and andropogon gayanus are few examples of grass species. Due to urbanization process deforestation activities is on the increase within and around Ilorin with its consequence effect on runoff generation.

\section{Methodology}

Data used in this study consists of rainfall, temperature and evapotranspiration values obtained for the period 2001 to 2010. Rainfall and temperature data were collected from Nigerian Metrological Agency (NIMET) at Ilorin International Airport while evapotranspiration values were computed from the temperature records obtained from the above named weather station based on modified Thorntwaite (1948) formula as adopted by Mands (1993). The modified Thornwaite (1948) formula was used in this study because the original equation has been found to be defective when the mean monthly temperature is greater than $14^{\circ} \mathrm{C}$. The new formula used is of the form:

$$
\mathrm{PE}=16\left(\frac{10 \mathrm{tm}}{\mathrm{J}}\right) \mathrm{a} \quad(\mathrm{mm} / \text { month }), \text { where }
$$

$\mathrm{PE}=$ Potential evapotranspiration,

$\mathrm{tm}=$ mean monthly temperature in ${ }^{\circ} \mathrm{C}$,

$\mathrm{a}=0.018 \mathrm{~J}+0.5$,

$\mathrm{j}=$ monthly radiation index,

$=0.09 \mathrm{tm}(1.5)$, and

$\mathrm{J}=$ Annual Radiation index $=\quad$ Sum of monthly $\mathrm{j}$

Though calculating potential evaporation using this formula may yield a slightly higher values in rainy season as the formula is based on temperature readings (Garnier, 1968), the formular according to Olaniran (1983) still retain its validity. Water budget graph for the city was subsequently plotted using the mean rainfall and evapo-transpiration data for the study period.

\section{Results and Discussion \\ Temporal Variations in Rainfall Values}

Table 1 presents the rainfall data for the period under review. Lower rainfall values were recorded in the months of January, February, November and December.

The table further shows that the month of September received the highest mean monthly rainfall for the study period and this represents more than $20 \%$ of the total mean monthly rainfall value for the study period. The month of February exhibits the highest rainfall variability while September exhibits the least variability. Year 2001 recorded the least rainfall amount while the highest rainfall amount was recorded in the year 2008.

The rainfall data further revealed that annual rainfall received between years 2003 and 2009 were higher than the mean annual rainfall of $1,200 \mathrm{~mm}$ for the study area. This increment may not be unconnected with incidence of climate change. Available records from previous reports like Beniston (2002), IPCC (2002) and Adefolalu (2003) have revealed that amount of rainfall amounts and its frequencies in different parts of the world have gone up triggering the occurrence of environmental hazards such as flooding erosion and sedimentation.

Temporal Variation in Mean Monthly Temperature for the Study Period

Table 2 shows the mean monthly temperature readings in the study area. The table shows that mean monthly temperature in the study area remain fairly constant with the month of August recording the lowest mean monthly temperature of $25.1^{\circ} \mathrm{C}$.

\section{Temporal Variation in Evapo-transpiration} Rate in the Study Area

Table 3 shows the computed mean monthly evapo-transpiration values for the study period. Evapo-transpiration rate in the study area ranges between $118 \mathrm{~mm}$ observed in the month of August and $142.3 \mathrm{~mm}$ observed in March. Evapo-transpiration values were generally high between the months of February and May and in 
November. These periods falls mainly within the dry season in the study area when the tropical continental air mass is dominant. This wind which is usually dusty carries no moisture hence the high evapotranspiration values during this period. Olaniran (1983) has earlier observed similar pattern in evapo-transpiration values in the study area.

\section{Water Budget Position in the study Area}

Figure 2 presents the mean water budget situation in the study area for the study period The graph indicates that soils in the study area have water deficit between mid October and late April in the study period. Significant water surplus was however observed between the months of May and October. The month of August however only recorded little water surplus situation. Reason for this low level of water surplus may not be unconnected with short dry spell which is usually experienced in the study area around this period.

\section{Management Implications of Research Findings}

Result from this study has a profound influence on basin management process in the study area. Water budget situation observed in the study will affect not only the hydrological processes in the city, but will also influence the practice of arable farming within and around the city. Soil water budget situation plays a significant role in flood generation. This is through its effects on run off generation (Horton, 1933). High soil moisture status encourages flooding because the ground is usually saturated during this period. For any basin experiencing high moisture status in its soil, an insignificant rainfall in such a basin can even trigger flood. Hence, adequate care must be taken by the residents of Ilorin between the months of May and October to prevent the adverse effects of hydro-meteorological condition of flood.

In the same vein, soil water deficit situation implies significant production in soil moisture required for plant growth. Arable farming activities should thus be prepared to embark on irrigation practices between the months of November and April to prevent crop failure.

\section{Conclusion}

Water budget situation of any catchment is an important issue in many aspects. Apart from being agriculturally useful in meeting food requirement of man; it is also environmentally significant as it influences flood generation. Hence concerted efforts should be made to monitor it in order to prevent food shortage and incidence of adverse hydro-metrological event of flood.

\section{References}

Adefolalu, D.O (2005), Climate Change and Health Implications in the Tropics Trop. Eviron, I.G.U. Climate Note. 30:201-210

Atoyebi, J.O (1995), Infiltration in Urbanized Basins in Ilorin, Kwara State". Unpublished Ph.D Thesis Geography Dept. University of Ilorin, $239 \mathrm{pp}$.

Ayoade, J.O (1998) Tropical Hydrology and Water Resources. Macmillan Publishers

Ayoade, J.O. (1997) Evaporation and Evapotranspiration in Nigeria. Journal of Tropical Geography 45:9-119.

Beniston, M. (2002) Climate Change: Implications for Hydrological Cycle and for Water Management. Kluwer Academic Publishers, London 501pp.

Garnier, B.J (1968) Using Potential Evapotranspiration as a guide to the water requirement crops. Nigeria Meteorological Service. Tech. Note 37

Horton, R.E (1933) The Role of Infiltration in the Hydrologic Cycle. Trans. Amer: Geophys.

IPPC (2002) Impacts, Adaptations and Mitigation of Climate Change: Scientific Technical Analysis. Contribution of Working Group II to the Second Assessment Report of the IPPC, Cambridge University Press.

Iroye, K.A. (2008) Effects of Landscape and Climatic Parameters on Basin Management Unpublished Ph.D Thesis Geography Dept.

Jackson, I.J. (1977) Climate, Water and Agriculture in the Tropics, Longman, London Jimoh, H.I (1997) Individual Rainfall Events and Sediment Generation on Different Land-Use Surfaces in Ilorin, Nigeria. Unpublished Ph.D Thesis, University of Ilorin.

Jimoh, H.I and Iroye K.A (2009) Managing High Runoff Discharge in the Urbanized Basin of Asa River Catchment Area of Ilorin, Nigeria. Olaniran, J.O, (1983) Flood generating Mechanism in Ilorin, Nigeria Geographical journal 7 (3):271-277.

Olaniran, O.J, (2002) Rainfall Anomalies in Nigeria: The contemporary understanding $55^{\text {th }}$ inaugural lecture, university press, Ilorin 66pp.

Oyegun, R.O, (1983) Water resource in Kwara State. Matanmi and sons printing and publishing co. Ltd Ilorin 113pp. Paris: United Nations Educational, Scientific, and Cultural Organization. 
Slatyer, R.O. (1967) Plant-water relationship, Academic press, London.

Tinuoye, A. (1990) Climatic condition in Dry and Wet years at Ilorin. Unpublished B.Sc. project works, university of Ilorin 125pp.
Winter, E.J. (1974) Water, Soil and the Plant, Macmillan, London.

Table 1 Rainfall Data for the Study Period

\begin{tabular}{|c|c|c|c|c|c|c|c|c|c|c|c|c|c|c|}
\hline MONTHS & 2001 & 002 & 2003 & 2004 & 2005 & 2006 & 2007 & 2008 & 2009 & 2010 & SUM & MEAN & STD & C.V\% \\
\hline JAN & 0 & 7.2 & 0 & 2.1 & 0 & 0.6 & 0 & 0 & 11.1 & 0 & 21 & 2.1 & 3.883 & 185 \\
\hline FEB & 0 & 0 & 0 & 0 & 8 & 1 & 0 & 0 & 1.2 & 0 & 10.2 & 1.02 & 2.495 & 245 \\
\hline MAR & 139 & 28.4 & 25.3 & 45.1 & 60.1 & 79.4 & 31.6 & 20.5 & 17.9 & 29.4 & 351.5 & 35.15 & 20.64 & 58.7 \\
\hline APRIL & 53.3 & 106.7 & 81.5 & 77.5 & 108.8 & 97.5 & 98.9 & 106.1 & 223.9 & 73.5 & 1027.7 & 102.77 & 46.16 & 44.9 \\
\hline MAY & 145.1 & 45.8 & 98 & 210.3 & 255.7 & 192.4 & 285.5 & 42.3 & 76 & 95.1 & 1446.2 & 144.62 & 87.15 & 60.3 \\
\hline JUNE & 137.3 & 96.8 & 370.8 & 310.4 & 211.5 & 129.7 & 158.2 & 241.1 & 177 & 89.3 & 1922.1 & 192.21 & 92.27 & 48 \\
\hline JULY & 85.1 & 160 & 94.2 & 192.5 & 133.8 & 195.4 & 199.3 & 318.6 & 313.4 & 95.1 & 1787.4 & 178.74 & 82.24 & 47.1 \\
\hline AUG & 57 & 257.9 & 80.7 & 156.8 & 63.8 & 86 & 134.1 & 226.3 & 2.91 & 143.8 & 1415.5 & 141.55 & 71.15 & 50.3 \\
\hline SEPT & 173.6 & 93.3 & 400.1 & 187.9 & 271.5 & 259 & 241.7 & 270.3 & 185.7 & 267.3 & 2350.4 & 235.04 & 81.65 & 34.7 \\
\hline OCT & 21.9 & 155.1 & 125.7 & 104.1 & 179.8 & 250.7 & 152.9 & 224.5 & 122.8 & 148.3 & 1495.8 & 149.58 & 61.46 & 41.1 \\
\hline NOV & 0 & 408 & 18.4 & 9.2 & 1 & 0 & 0.3 & 4.8 & 4.4 & 11.4 & 55.4 & 5.54 & 6.005 & 108 \\
\hline DEC & 0 & 0 & 0 & 0 & 11.9 & 0 & 6.6 & 14 & 0 & 0 & 32.5 & 3.25 & 5.533 & 17 \\
\hline SUM & 697.1 & 957.1 & 1295 & 1295.9 & 1305.9 & 1291.7 & 1309 & 1469 & 1342.5 & 953.2 & & & & \\
\hline MEAN & 58.09 & 79.76 & 107.9 & 107.99 & 108.83 & 107.64 & 109.1 & 122.4 & 111.88 & 79.43 & & & & \\
\hline STD & 63.31 & 81.06 & 136.9 & 102.93 & 100.76 & 98.22 & 101.8 & 12.7 & 108.3 & 80.26 & & & & \\
\hline C.V\% & 109 & 101.6 & 126.9 & 95.3 & 92.6 & 91.3 & 93.3 & 101.1 & 88.5 & 101 & & & & \\
\hline
\end{tabular}

Source: Nigerian Meteorological Agency (2012) 
Water Budget Position and its Implications on Basin Management in Urbanized................Iroye, K.A.

Table 2 Mean Monthly Temperature for the Study Area

\begin{tabular}{|c|c|c|c|c|c|c|c|c|c|c|c|c|c|c|c|c|}
\hline Year & Jan & Feb & Mar & Apr & May & Jun & July & Aug & Sept & Oct & Nov & Dec & Sum & Mean & SD & CV \\
\hline 2001 & 2635 & 27.35 & 30.45 & 29.4 & 28.25 & 26.45 & 25.30 & 24.9 & 25.30 & 27.15 & 28.95 & 28.15 & 328.5 & 27.98 & 2.16 & 7.65 \\
\hline 2002 & 26.1 & 27.1 & 30.65 & 30. & 29.10 & 28.4 & 25.74 & 25.84 & 25.41 & 26.58 & 27.51 & 27.41 & 331.4 & 27.62 & 2.25 & 8.31 \\
\hline 2003 & 27.85 & 30.15 & 30.5 & 30.1 & 28.25 & 26.8 & 25.25 & 25.71 & 25.82 & 27.31 & 28.11 & 27.8 & 321.2 & 26.77 & 3.01 & 7.92 \\
\hline 2004 & 27.1 & 24.35 & 30.5 & 30.5 & 27.25 & 26.11 & 25.31 & 25.55 & 25.70 & 26.55 & 27.50 & 27.85 & 331.5 & 27.63 & 3.14 & 6.23 \\
\hline 2005 & 26.5 & 30.15 & 29.7 & 30.30 & 26.81 & 27.14 & 25.8 & 24.81 & 25.4 & 28.1 & 27.58 & 28.1 & 321.7 & 26.75 & 2.87 & 8.38 \\
\hline 2006 & 28.15 & 30.1 & 28.9 & 29.8 & 26.7 & 26.8 & 26.14 & 25.92 & 26.1 & 26.14 & 28.1 & 27.16 & 325.6 & 27.13 & 2.34 & 9.23 \\
\hline 2007 & 25.85 & 29.5 & 28.3 & 29.7 & 29.10 & 27.50 & 26.0 & 25.35 & 25.70 & 26.50 & 28.00 & 27.15 & 327.0 & 27.25 & 2.01 & 7.13 \\
\hline 2008 & 25.55 & 28.4 & 30.15 & 30.5 & 28.5 & 26.51 & 25.57 & 24.81 & 25.84 & 25.81 & 27.55 & 28.1 & 331.5 & 27.58 & 1.98 & 7.13 \\
\hline 2009 & 27.5 & 29.85 & 30.20 & 30.4 & 28.6 & 26.41 & 26.4 & 25.60 & 26.11 & 26.41 & 27.58 & 27.62 & 329.5 & 29.96 & 2.12 & 7.52 \\
\hline 2010 & 28.45 & 30.7 & 30.95 & 30.95 & 28.15 & 27.55 & 25.80 & 25.75 & 26.05 & 25.90 & 28.00 & 26.50 & 334.3 & 27.86 & 2.33 & 8.18 \\
\hline SUM & 268.5 & 292.9 & 302.7 & 291.4 & 277.9 & 265.6 & 256.1 & 251.1 & 257.5 & 265.3 & 276.3 & 270.6 & & & & \\
\hline MEAN & 26.85 & 29.29 & 30.27 & 29.14 & 27.79 & 26.56 & 25.61 & 25.11 & 25.75 & 26.53 & 2763 & 27.06 & & & & \\
\hline SD & 1.38 & 0.91 & 0.66 & 0.70 & 0.65 & 0.77 & $0.6 /$ & 0.53 & 0.61 & 0.62 & 0.94 & 0.95 & & & & \\
\hline CV & 4.74 & 3.67 & 2.51 & 2.01 & 2.35 & 2.58 & 2.10 & 1.38 & 1.20 & 2.38 & 3.96 & 4.87 & & & & \\
\hline
\end{tabular}

Source: Nigerian Meteorological Agency (2012) 
Ethiopian Journal of Environmental Studies and Management Vol. 6 No.4 2013

Table 3 Mean Monthly Evapo-transpiration Values for the Study Area.

\begin{tabular}{|c|c|c|c|c|c|c|c|}
\hline Month & $\begin{array}{l}\text { Mean } \\
\text { monthly } \\
\text { Rain }\end{array}$ & $\begin{array}{l}\text { Mean } \\
\text { monthly } \\
\text { Temp }\end{array}$ & $\begin{array}{l}\text { Monthly } \\
\text { Radiation } \\
\text { Index }\end{array}$ & $\begin{array}{l}\text { Annual } \\
\text { radiation } \\
\text { index }\end{array}$ & $\begin{array}{l}\text { 'a' } \\
\text { value }\end{array}$ & constant & P.E \\
\hline Jan & 2.1 & 26.85 & 3.62 & 44.25 & & 1.3 & 12.2 \\
\hline Feb & 1.02 & 29.29 & 3.99 & 44.25 & & 1.3 & 139.1 \\
\hline Mar & 35.15 & 30.27 & 4.08 & 44.25 & & 1.3 & 142.3 \\
\hline April & 102.77 & 29.14 & 3.93 & 44.25 & & 1.3 & 137.0 \\
\hline May & 144.62 & 27.79 & 3.75 & 44.25 & & 1.3 & 130.6 \\
\hline June & 192.21 & 26.56 & 3.59 & 44.25 & & 1.3 & 124.8 \\
\hline July & 178.74 & 25.61 & 3.46 & 44.25 & & 1.3 & 120.4 \\
\hline Aug & 141.55 & 25.11 & 3.39 & 44.25 & & 1.3 & 118.0 \\
\hline Sept & 235.04 & 25.75 & 3.48 & 44.25 & & 1.3 & 121.0 \\
\hline Oct & 149.54 & 26.53 & 3.58 & 44.25 & & 1.3 & 124.7 \\
\hline Nov & 5.54 & 27.63 & 3.73 & 44.25 & & 1.3 & 129.9 \\
\hline Dec & 3.25 & 27.06 & 3.65 & 44.25 & & 1.3 & 127.2 \\
\hline
\end{tabular}

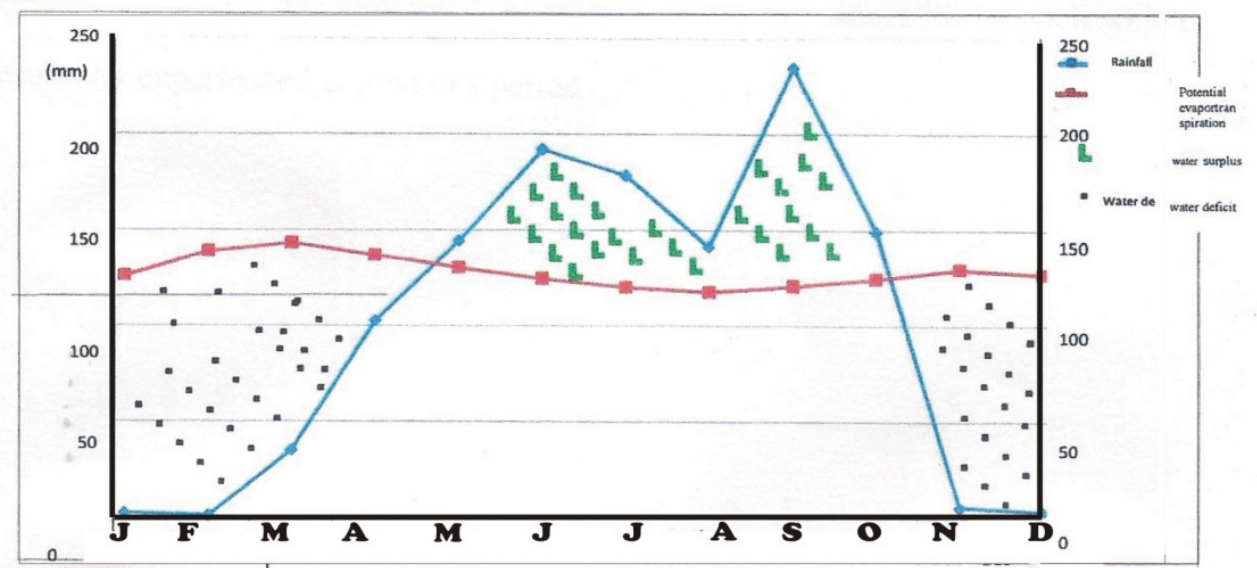

Figure 2 Mean Water Budget Situation in Ilorin for the Study Period (2001 - 2012) 